\title{
1 Workers called white and classes called poor
}

\author{
The "White Working Class" and \\ "Poor Whites" in Southern Africa, \\ 1910-1994
}

Jonathan Hyslop

\section{Introduction}

By 1910, the countries of Southern Africa represented more than just geographical contiguity; they were coalescing into an economically connected region. In that year, the line of rail from the south reached the mines of Katanga in the southern Congo, joining Elisabethville to a steam-powered transport network stretching through the Rhodesias, to the South African ports and Lourenco Marques. Yet too often the history of the unified South African state, which was being established at the same time, has been dealt with in relative isolation from the region, in a kind of South African exceptionalism. And amongst the subjects that South African historiography treats of, that of the "white working class" and "poor whites" has been particularly strongly assumed to reflect the peculiarities of the country. In superficial accounts, the notoriously confused slogan of the Rand 1922 miners' strike, 'Workers of the World, Unite and Fight for a White South Africa', is sometimes presented as a kind of emblem of the uniquely bizarre history of South African white labour. But the white labour question in South Africa was much less unique in its dynamics than is often assumed. What happened within the boundaries of the South African state was paralleled in, and connected to, a wider world. So how could the question of white workers in southern Africa look if we thought about it in a transnational, Southern African framework? Does the manner in which "subaltern" whites figured in the social order and politics of the South African racial state, between its formation in 1910 and its political democratisation in 1994, appear different if reconsidered in relation to what we know about similar groups in the other countries of the region?

There are two relatively obvious ways in which such a rethinking can proceed. The first is to take a comparative approach. There were for example some clear similarities and important differences in how political issues played out in Southern Rhodesia and in South Africa. But this method has its limitations. It tends to assume the existence of neatly separate entities which can be compared. This can lead to attributing greater coherence to what transpired within territorial boundaries than is necessarily warranted, and to ignore the way in which networks of power, and social struggles, spilled across national 
or imperial borders. In Southern Africa, with its unfenced and often thinly patrolled borderlines, and its long-lasting flows of capital and labour across imperial boundaries, it is especially misleading. Both workers and those who sought to dominate them, cooperated and competed across borders to a far greater extent than a nationally constrained imagination allows for. So it is crucial to consider, as a second approach, the connections which contemporary scholarship calls "transnational". But I also want to pursue a third axis of inquiry. Workers, capitalists and state leaders responded not just to local or regional concerns, but to the great global ideological struggles over political and economic questions and to the economic conjunctures that accompanied them. I call this dimension "contemporaneity": here one considers the way in which political actors framed what they were doing in relation to globalscale ideologies and to events to which they may or may not have had direct connections. Actors read, or creatively misread, the wider world for their own purposes. White workers and white elites often made reactionary choices - but they were not parochial. They often had an astute awareness of the global political contexts in which they operated.

This chapter then, uses the three methodological tools of comparison, the study of connections and the study of contemporaneity to reconsider the literature on the poor white and white working class in South Africa in a regional and a global context. What questions though are we attempting to answer? Three lives which cross regional boundaries provide a starting point for formulating lines of inquiry.

E.J. Brown came from Australia to the Rand before the First World War. He participated in the leadership of the great New Kleinfontein strike of white workers in 1913, which resulted in a bloody general strike in Johannesburg and short-term victories for the miners. They were crushed by the imposition of martial law in the next year. Brown moved on to the Katanga mines of the Belgian Congo. There, in 1919 to 1920 he led an extraordinarily militant strike wave of the predominantly British and South African white miners around Elisabethville, which included a dynamite attack on the office of the attorney general and the blowing up of a trestle bridge and railway engine. Deported back to South Africa, Brown last shows up in the historical record in a 1921 letter from the embryo South African Communist Party to the Comintern headquarters in Moscow, listing their leading militants. ${ }^{1}$

"Anna Prinsloo" was born in 1916 in the Afrikaner community of Humpata in Angola. These Boers lived in an only partially monetised economy, grazing their cattle and trading and bartering with the Portuguese, the Moemereya and the Ovambo. They were targeted for "saving" as "poor whites" by Afrikaner nationalist ideologues and in 1928 many, including Anna's family, were persuaded to move to South African-ruled South West Africa. Anna's father was allocated some land there, but it was inadequate to support the family. The teenage girl, who was not fully literate, was forced to seek work as a cleaner and washerwoman first in Gobabis, then in Windhoek. She had two children, possibly out of wedlock. Taking her daughter to Cape Town for medical treatment, 
she was a domestic worker for a doctor in Rondebosch, before happily moving to a much better paid job in a garment factory. Returning to South West, she eked out a living making charcoal on her father's farm. In 1945, Anna married a marginal Afrikaner farmer from Ghanzi in Bechuanaland and moved with him to the British territory. The struggling couple tried to break into small business: they set up a modest transport business and Anna borrowed money to run a café for African migrant workers. After her husband's death left her deep in debt, Anna, who had acquired a heavy-duty license, went back to the transport business. She drove her truck along the desert roads accompanied by four or five African employees, sleeping on the ground at the side of the vehicle by night. By 1973, she was planning to take out citizenship in the now independent Botswana. ${ }^{2}$

Born in 1930, Maria de Lurdes Delgado grew up in central Portugal's Beira Baixa region. She emigrated to Mozambique in 1953 to marry a local man who had gone to work as a foreman on the railways. Maria, who had not completed primary school, took this step to escape a life of manual labour in her tyrannical father's vegetable garden. Daniel however turned out to be a brutal and unfaithful husband. Maria spent fifteen miserable years in remote rail stops in the Mozambiquan interior, suffering illness, a sense of social isolation, and fear of the animals, snakes and scorpions. The couple had two children, but their daughter contracted polio. Maria took her to Johannesburg several times for treatment: there she felt humiliated by her lack of English and her struggle to pay the bills. By 1968, alarmed by the Frelimo insurgency, Maria and Daniel decided to move to South Africa. They had to evade the secret police in order to do so, as emigration was not permitted by the authoritarian Portuguese regime. In Johannesburg, Daniel found work as a welder. Maria's daughter became pregnant by a relative, and Maria took on raising the child. Then Daniel and their son were in a terrible car accident. The boy survived, but Daniel died. Only now did Maria's life change for the better. Her house was paid off by Daniel's insurance, and she also received a small but significant cash payment. She found work and learned to drive. Maria then met a Portuguese refugee from Angola, a kind man called Fernando. They married and were happy together. The couple moved to East London and opened a restaurant, which was highly successful. For the first time in her life Maria experienced a modest prosperity, and her children also did well in South Africa, establishing middle-class careers for themselves. ${ }^{3}$

The by now very considerable social history literature on South Africa has paid a great deal of attention to the questions of the histories of poor and working-class whites. But the stories of E.J. Brown, "Anna Prinsloo" and Maria Delgado are striking because they run, if not exactly in contradiction, then at tangents, to the accepted wisdom. On the one hand work on the white working class in South Africa has largely concentrated on the labour movements created by in the early decades of the Twentieth Century. This literature has explored the vicious class conflicts between white unions and the Rand mine owners and other capitalists. ${ }^{4}$ It has emphasised the racial protectionist politics 
of these unions, and has provided an understanding of how the leadership of a number of them were captured by Afrikaner nationalists in the 1940s. ${ }^{5}$ On the other hand scholarship has shown how poverty and unemployment amongst whites during the period of urbanisation in the first three decades of the century, provided the context for the political construction by white, and especially Afrikaner, intellectuals of the "poor white question". 6 The gap between the racial status and the economic position of a white underclass was seen as a threat to white dominance. Across the range of work carried out in these fields, there has tended to be a belief that these social cleavages in white South African society were ultimately overcome by the action of the South African state. The 1930s saw the mobilisation of the radical wing of Afrikaner nationalism under D.F. Malan around the poor white question. It is now widely assumed that the policies of the Apartheid government, initiated from 1948 by Malan as prime minister, eliminated white poverty and created mass-scale transformation of white workers and poor people - or at least their children - into the middle, professional and business classes. This view that the white working class ceased to be a significant social or political force in South Africa is what I would call the "thesis of incorporation". But as will be shown, this is a mischaracterisation of the changes in the class structure of South Africa, and a misreading of its political dynamics. And it is equally misleading when it is applied to the other countries of the region.

The stories of these border-crossing lives provoke different kinds of questions from those which have conventionally been posed. Should not the migration of white workers across national boundaries in the region become a more central part of our understanding of white labour questions? Does Brown's career point to a white labour movement history which need to be read regionally? Does that career also not suggest the need to give greater weight to the influence of global forms of labour political radicalism on white workers Southern Africa? At the same time Anna and Maria's lives remind us that the history of white workers cannot be conflated either with the histories of white labour organisation or of Afrikaner nationalism. Why have the histories of Portuguese workers and other continental European-origin ethnic groups not been much integrated into the stories we have told about white labour? Was the upwards mobility which many white working-class people - including Anna and Maria - certainly did experience across time actually as solid as is often assumed: or was it - as in Anna's case - in reality somewhat tenuous? And if there was a transformation in the conditions of the white poor in South Africa, is the standard narrative about the role of Afrikaner nationalism in it really justified? Anna, after all, despite being the recipient of the beneficence of an early and energetic manifestation of the politics of poor-white-saving, and despite certainly partaking in some of the racial attitudes of white Southern Africans, seems to have been impervious to the appeals of Afrikaner nationalism. Turning her back on the considerable racialised social benefits she would have enjoyed in South West or South Africa, she saw her future in a now-independent black ruled state. Just how incorporated were the white working class? 


\section{Artificial boundary-drawing and naturalised racial categories}

We need to question the tendency to naturalise the very terms "white working class" and "poor white". To be "white" was not of course to possess any particular biological attribute or national origin. To take a striking example the term "gens du couleur" (people of colour) was commonly and indeed legally used in the Belgian Congo's Elisabethville to denote the marginal Italian, Greek and Portuguese traders who catered to African customers. ${ }^{7}$ Colour could, as it were, be acquired or lost. White people were simply people who the social order called white. Who was included or excluded from such a category was a matter of extremely arbitrary historical contingency.

There were important divergences in the racial ideologies of different colonial states, which affected the way white identity was managed - and these techniques themselves varied across time. This made processes of drawing racial boundaries crucial to the way states constituted themselves. The existence of people called "white" whose standard of living was similar to or below that of colonial subjects, and the physical and cultural proximity to colonial subjects that this inherently involved, was almost universally seem by dominant groups as threatening the assumptions of superior white propensity to achievement. ${ }^{8}$ But very different strategies were pursued to "solve" this problem.

"The Poor" has historically tended to be a category imposed from outside: through it, dominant classes constitute groups of people as objects of charity, or of coercion, or as targets for projects of social reform, and in the process reinforce their own power. In Southern Africa category of "poor white" tended to be one imposed from above on working-class and lumpenproletarian people by elites, seeking both to name them as a problem for to be solved, and as a group to be mobilised around the imputed racial identity. This often - although not always - involved removing them from zones of social ambiguity in which they were living in boundary-blurring proximity to people designated as "nonwhite". The term "Poor White" seeks to displace a potential class identity with a racial identity by constituting poverty as an anomaly in racial status rather than a product of capitalist social relations.

The "white working class" on the other hand tended initially to be selfdesignated, as white workers sought to leverage prevailing racial discourses to demand particular privileges on the basis of an assumed racial identity. This selfidentification was however often manipulated by elites, who, in the interests of increasing their own political advantage, sought to move white workers to more intense forms of boundary policing. One could thus say that poor whites were workers who were told from above that their racial identity was more important than their poverty, while the white working class were workers who demanded of capital and the state that their racial status should be specially protected in the labour market (sometimes with encouragement from more privileged strata).

The different ways in which racial boundaries were drawn in different states had real effects. There is a tendency to assume that because all the states we are 
looking at here were racist - as indeed they were - the differences in the ways in which they operated can be regarded as minor. But this is an error - the differences were real and significant. Perhaps the most important example arises in the case of the Portuguese colonies after the Second World War. As the Portuguese government turned towards the new colonial policy, it adopted an ideology based in the writings of the Brazilian scholar Gilberto Freyre. His term, "Lusotropicalism" put forward a notion of the Portuguese colonial enterprise as based in a supposed natural genius of the nation for racial boundary-crossing. This was a blatant attempt to sell the Portuguese Empire to a world in which narratives of racial superiority were under attack. And it has consequently been rightly debunked by many scholars, who have correctly pointed out the racist nature of the imperial project. ${ }^{9}$ Yet this debunking can lead to a neglect of the ways in which Portuguese policies were actually at variance with those of South Africa or Southern Rhodesia. Boundaries were more porous in the Portuguese colonies and that created a set of different dynamics in the social situation of the white poor and working class. Schools and working-class residential areas were not rigidly segregated, whereas in the South Africa and Rhodesia of the time they were. All countries in the region were racially structured societies, but their racial structures worked in significantly different ways.

Nor were "whites" a solid bloc of equal status. There were also aspects of intra-white ethnic or status distinction which cut across the logic of a primary racial identification, such as the very intense Anglophone - Afrikaner divisions in the British empire countries. The Portuguese attempt to create a colonial community was bedevilled by the self-inflicted wound of a difference in status between the Portuguese-born, referred to as "first class whites", and the colonial-born descendants of settlers, known as "second class whites". ${ }^{10}$ The latter were not eligible for significant positions in the colonial administration and had no automatic right to travel to Portugal. Although the legal distinction was set aside late in 1950, it was embedded in settler culture as a status distinction right to the end of Portuguese rule. ${ }^{11}$ Moreover, in South Africa and the Rhodesias, anti-Semitism and intense hostility to Portuguese, Greeks and other white minorities, often underpinned by racist ideologies, were quite common.

\section{The persistence of class}

The persistence of class amongst Southern African whites, and its continuing political effects are important to recognise. The South African white occupational structure remained strikingly pyramidal right to the end of apartheid. And intra-white class differentiation was even more strikingly the case in the Portuguese colonies, especially Angola, where there was a very substantial marginalised white underclass throughout the colonial period. Class divisions amongst whites continued to affect politics to the end of the racial states, in ways which cannot be understood purely by focusing on the racial politics side of the equation. This is not in any way to diminish the centrality of the racial systems, and the extent of the social advantages they gave to those identified 
as white. But it is to say that we cannot assume class differentiation amongst whites declined into relative social and political insignificance. The thesis of incorporation is far from valid either for South Africa, or for other countries in the region.

Certainly there was at particular times, large scale white upwards social mobility or improvement in living standards. In South Africa, the white working class experienced remarkable levels of wage increases between the 1940s and the early 1970s. In that country, there was also a growth of the white middle class, in a halting and uneven way from the interwar years, and spectacularly in the 1940s to 1970s. In Southern Rhodesia there was also widespread growth in white affluence in the post-Second World War years. Portuguese colonists improved their economic and educational position in the same period compared to the population in the home country (although not to the same extent as white South Africans or people in the richer west European countries). ${ }^{12}$ However, it is important not to fall for the idea of a universal prosperity or the disappearance of class. Moreover, there was a clear economic decline of the working class in the region from the 1970s. The economic security of the white working class in Rhodesia faltered in the last decade of white rule. In South Africa, by the 1980 s, with a turn to free marketisation, very visible white poverty had reappeared.

It is important to note though for all the relative prosperity and upwards social mobility of the 1940s to the 1970s, neither South African nor the Portuguese colonial whites were predominantly middle class. In South Africa most white employees remained in working-class positions. In the mid-1960s whites occupied the vast majority of artisan and apprentice positions, three quarters of all routine white collar jobs and nearly half of the mostly low-skilled security jobs, as well as constituting significant minorities of semi-skilled operatives and low level service workers. Only at the lowest level of unskilled jobs, were whites more or less absent. ${ }^{13}$ In the Portuguese colonies class differentials were even more striking. In the Angolan cities of the 1950s there was a clear elite layer, living in almost exclusively white suburbs. But below that was a very modest middle stratum of artisans, clerks, minor civil servants, poor farmers and skilled transport workers. In stark contrast to the rigid social segregation prevailing in the South Africa and Rhodesia of the time, this group were somewhat socially integrated with the displaced descendants of the old, mixed-race and black trading elite and the assimilados (Africans granted Portuguese citizen status). The poorest whites - unskilled workers, struggling craftsmen, taxi drivers and the indigent, lived in the slums of Luanda, Lobito and other towns amongst black and mixed-race neighbours. ${ }^{14}$ In Mozambique during the 1970s, there is evidence of significant class distinction in white society; for example, in urban schools, white working-class pupils experienced a strong sense of social discrimination, and unlike the white elite often had social links with black pupils. ${ }^{15}$

Even at the end of apartheid, it is important to note how large the section of South African whites who had not risen into the middle classes remained. Notwithstanding changes in production processes towards techniques such as 
modularised concrete building, which did not require traditional artisan skills, white numbers in the artisan trades and apprenticeships remained steady. There were over half a million white clerical employees, with women occupying a significantly increasing proportion of the workforce. There were still large numbers of white semi-skilled operatives and the numbers of white security employees had actually grown. ${ }^{16}$

\section{Working-class access to political power}

Varying forms of white working-class access to political power and the different levels of organization that allowed, was crucial to the political shaping of these societies. Participation in formal political systems and meaningful unions was central in white workers' ability to shape politics, and the degree of power they exercised had real effects. This is demonstrated in a negative way by the direction of events in the Portuguese colonies. With the imposition of a dictatorship in metropolitan Portugal in 1926, which was to last for another nearly five decades, Portuguese-origin workers in the colonies lost the democratic rights that they had enjoyed and exercised during the liberal republic founded in 1910. In Lourenco Marques the substantial wage and benefit structure built up over previous decades by the port and railway workers was demolished. ${ }^{17}$ In 1930-1 serious political disturbances in Angola by political deportees, provincial autonomists and soldiers was crushed by the army, and troublesome white working-class radicals were repatriated to Portugal in significant numbers. ${ }^{18}$ While it is possible to debate whether Antonio Salazar's Estado Novo (New State), founded in 1934, was exactly fascist, it certainly belonged to the family of European authoritarian governments of the interwar years, and it outlasted all of them except Franco's Spain. ${ }^{19}$ Although political activity was not entirely suppressed, white workers lacked any form of meaningful unionisation or political representation. Bogus sindicatos substituted for labour organisation and local government was subordinated to the central state. Not only did this repression prevent workers from shaping the politics of the colonial era, but it also meant that they lacked the political resources to impose their demands in the moment of the collapse of the empire in 1974-5. In September 1974 a hopelessly bungled settler coup in Mozambique against the Portuguese revolutionary government's political handover to Frelimo, crumbled rapidly. It precipitated a mass flight of whites to South Africa. ${ }^{20}$

Somewhat similarly, in the Congo, during the early 1920s, mine management replaced white South African and British workers with Belgians, especially economically vulnerable miners from the depressed Hainaut region. On short-term contracts and cowed by the prospect of unemployment at home, they remained quiescent throughout the inter-war years. Elizabethville became a conservative Catholic-dominated enclave. ${ }^{21}$ There was some brief labour insurgency by Belgian workers at the start of the 1940s, precipitated by the special conditions of wartime, but by and large they had little opportunity to express themselves politically throughout the rest of the colonial period. 
By contrast, white workers in South Africa and Southern Rhodesia, having attained effective participation in the parliamentary system from 1910 and 1923 respectively, were at times able to use it quite effectively to advance their perceived interests. The South African Labour Party (SALP), a trade union based party rooted in the British immigrant working class was able to conclude an alliance with General Hertzog's National Party to form a "Pact" government in 1924. The SALP's influence on the policies of the Hertzog cabinet resulted in pro-white labour legislation that formed the template for the policies that were to prevail for over five decades. The creation of a parastatal electricity provider and iron and steel company was carried out with a special mission to provide jobs for working-class whites. The favouring of white workers on the state owned railway system drove out workers of colour from unskilled jobs on a huge scale. The "rate for the job" protecting white artisans against African labour competition was institutionalised. Wage boards were empowered to uphold minimum wages, and this was used to push employers to hire more white labour, creating a considerable influx of white Afrikaner women into industrial work in this period. Most importantly of all, the Hertzogites implemented an extensive system of white pensions, disability grants and welfare payments. This general approach was maintained and actually extended by the coalition of Hertzog with Smuts from 1933. The 1934 Slums Act created the basis for extensive social housing construction for whites. And when a now more socio-economically pragmatic Smuts took over in 1939 he continued in the same direction. ${ }^{22}$ The idea that the post-1948 Nationalist government "saved" the white working class is greatly exaggerated and owes a lot to its own propaganda. After 1948, Malan and his successors merely continued established social policies, with a somewhat higher level of spending and a greater emphasis on Afrikaner ethnic interests.

The Rhodesias represent an intermediate case, with an initial very hostile environment for the white working class later shifting to a more hospitable one - although never quite as favourable as in the South African case. In the 1920s and 1930s, Southern Rhodesia was a particular bastion of rigidly free market politics. In these years white workers there suffered repeated wage cuts and retrenchments. State health care, pensions, housing and welfare services were almost entirely lacking. Management and government took a tough stance towards labour organisations, in the context of a generally depressed economy. ${ }^{23}$ Unsuccessful white farmers also suffered economic devastation as commodity prices declined: experiences of absolute white rural indigence are recounted by Daphne Anderson in her autobiographical novel The Toerags. ${ }^{24}$ In response, the Rhodesian Labour Party became strong, capturing about a third of the seats in the legislature by 1939. The Second World War marked an important break, with Huggins absorbing some Labour leaders into his government and turning towards a more economically interventionist state.

Roy Welensky was able to use his position as an originally labour-based leader of the whites in Northern Rhodesia during the 1940s, to leverage a massive political transformation of the region. The son of a ne'er-do-well Jewish father 
and an Afrikaner waitress mother, and famously, in his own description " $100 \%$ British", Welensky had grown up on the literal wrong side of the tracks in his parents' seedy boarding house on Salisbury's Pioneer Avenue. As a teenager he trained as engine driver and became a boxing champion. He was an activist in the railway union, where he became steeped in the classical literature of the British socialism. After being transferred to Broken Hill in Northern Rhodesia as a punishment for his union militancy, he applied his considerable political talents to become leader of the labour group in the legislature and from there was able to become dominant figure in Northern Rhodesia settler politics. It was from his base in the labour movement, and success in the legislature that Roy Welensky launched his bid for a Central African Federation. ${ }^{25}$ Welensky's project was perhaps the most ambitious to emerge from the world of white labourism in the modern history of Southern Africa. His aim was, through the Federation, to unite the settler political power of Southern Rhodesia with the now fabulous copper-mining based wealth of Northern Rhodesia. ${ }^{26}$ It was the growing presence of Afrikaner workers in the Rhodesias that seems to have been crucial to the British government's ultimate accession to the Federation. Particularly after Malan's "Purified" Nationalists took power in 1948, the fear of both British Conservatives and British Labour was that rejection of the settlers' demands would drive the Rhodesian whites into the hands of the South Africans, creating a huge and aggressive white geopolitical bloc that would come into conflict with future independent African states, and impose South African - style policies internally. The misguided British conclusion that the Federal structure would allow Westminster to moderate racial policy, gradually create greater African representation and resist South African influence, provided Welensky with the gap in which he could pursue his policy. ${ }^{27}$

\section{Regional working classes and global politics}

White working-class political organisations need to be understood not just as local phenomena but as possessing specific links across the region, and into the outside world, which had important local effects. Before the First World War, there was a global British labour network, connecting the settler colonies and the empire, and it articulated an ideology of white labourism, in which colonised workers were seen as a "cheap labour" threat to white workers. This programme for protecting the position of white workers was crucial to the political development of South Africa and Australia especially, but was also largely accepted in Britain itself. ${ }^{28}$

In Southern Africa the period from 1910 to 1923 was one of harsh confrontation between, on the one hand, politically powerful capital and weak but violent states, and on the other militant white workers, most of whom supported racial protectionism. The great strikes of white workers on the Witwatersrand in 1913 and 1914 and the insurrectionary Rand general strike of 1922 were the high points of this movement. The South African Labour Party became a powerful embodiment of this politics. Because of the multiple connections 
of British immigrant and white South African activists to other countries in the region, this militant mood spread. On the Rhodesian railways and mines, there were large scale strikes in 1919 and 1920. A Rhodesian Labour Party emerged with an anti-big business message. ${ }^{29}$ And as we have seen, the period also saw militant action by British and South African workers on the mines of Katanga. White Labourism never again returned to this level of mobilisation, but it continued to be a transnational force in the region. Their mobilisation of British and South African workers on the Northern Rhodesia mines in 1940, for example, laid the basis for the highly favourable post-war employment conditions which they attained. ${ }^{30}$

But white labourism was not the only global trend to influence white labour in the region. There are four other important international networks that are notable in Southern Africa. The first is that of the syndicalism of the period of roughly 1910 to 1923 . Small numbers of Syndicalists, with their brand of revolutionary trade unionism, emerging out of the British and Australasian movements of the early twentieth century were often in those years able to seize the leadership of significant numbers of workers, even though unionists were usually more conservative or white labourist than they. The Syndicalists' effective organisational tactics - although not their relatively advanced views of racial politics - attracted broad support at moments of crisis. A number of key individuals in the Rhodesias had been exposed to international syndicalist militancy in Britain or South Africa in the pre-war years. For instance, Jack Keller, the leader of the Rhodesian railwaymen and founder of the Rhodesian Labour Party had participated in the 1911 British railway strike. ${ }^{31}$ Union militancy fed into a wave of white populism, as white workers played a prominent part in defeating a proposed unification with South Africa in the 1922 referendum, with activists viewing the Smuts governments repression of the Rand miners' strike as a manifestation of the fate that awaited Rhodesian workers.

There was also a strain of syndicalism in the Portuguese colonies, but on a more minor scale and inhabiting a different, Iberian cultural world. Syndicalist activism and industrial action was particularly strong amongst the railway workers of Angola (especially Lobito) and in the port and railway system of Lourenco Marques. ${ }^{32}$ The role of syndicalists - many of them after 1917 sympathetic to the Russian Revolution - and the intensity of the labour struggles up to 1923 , is crucial to understanding the intensity of upper class fear of the potential for white workers to be drawn into potentially dangerous political paths, across a very long subsequent period.

Secondly, partially but not entirely overlapping with white labourism, the mainstream of British social democratic politics and trade unionism had considerable links to labour groupings and unions in Southern Africa into the 1950s. Gradualist projects of social reform and Fabian attempts to moderate the harshness of the racial politics of empire had some impact in these circles. In the early 1940s, both South African and Rhodesian Labour Parties reflected the contemporary social policy radicalisation of the British Labour Party and 
the shift in the progressive British intelligentsia towards a more critical view of "scientific" racism. The SALP Mayoress of Johannesburg, Jessie McPherson, and the labour-connected mayoress of Salisbury (Harare), Gladys Maasdorp, for instance, were leaders who sought to move their organisations away from racist policies and towards a full social democratic programme. ${ }^{33}$

Thirdly, there were international communist networks, which though thinly represented in the white labour movement, attained positions of considerable influence on white workers at particular moments. Particularly remarkable was the success of the communist led servicemen's organisation, the Springbok Legion, in winning support amongst white South African troops in the North Africa in 1941-3. ${ }^{34}$ The figure of Frank Maybank stands at the confluence of white labourist, social democratic and communist political strands: a British-born Australian Communist who led the crucially important, racially protectionist 1940 white miners' strike in Northern Rhodesia, and who very successfully mobilised the leadership of the British Labour Party and trade unions to defend him. ${ }^{35}$ There was also a small scale level of underground activism of the Portuguese Communist Party in the Colonies. There was clandestine Portuguese communist labour activism in Angola and amongst white dockworkers in Lourenco Marques, which played a role in strikes there in the 1940s and 1950s. Dissent also surfaced in the form of the particular popularity in Angola and Mozambique of the leftist General Humberto Delgado, whose opposition shook the regime, first from within, and later from exile, before his assassination in $1965 .^{36}$

Fourthly, on the other side of the spectrum, the influence of international right-wing anti-communist trade unionism - strong especially in US, Australian and to a lesser extent British unionism in the late 1940s and 1950s - has perhaps been underestimated. Anti-Communism had a palpable effect on white trade unionists in the Rhodesias and South Africa between the 1940s and 1960s. Within the Afrikaner nationalists drive to take over the South African unions, Anti-communism was an ideological commitment of its own, and not just a cover for nationalism and racism. There was a genuine sense of fear that white workers were succumbing to the left-wing ideas of some of their union leaders. Senator Jan De Klerk characterised the campaign as an attempt to 'stem this wild flood of Communism'. ${ }^{37}$ Roy Welensky forms an interesting bridge, through anti-Communism, between the Southern African white labour tradition of the first half of the twentieth century and the rise of the international far right in the second half. By the early 1960s, Welensky attracted a significant section of British Conservative parliamentarians for his last-ditch attempt to save the Central African Federation: they included the young Margaret Thatcher. ${ }^{38}$ In Southern Rhodesia, in the late 1950s, white workers, reacting against the relatively liberal and paternalist racial policies of Prime Minister Garfield Todd, swung behind the populist racial protectionism. They ended up in the fold of Ian Smith's Rhodesian Front, which was saturated with "anti-communist"ideology and became closely aligned with the British and American extreme right. Anti-Communism has often been assumed to have been simply a cover 
for racial ideology in the region, but it was also a force with a life and political dynamics of its own. ${ }^{39}$

\section{The ambiguities of immigration}

Fear of the white working class and the creation of a poor white stratum was a major brake on the immigration of Europeans to the region throughout this historical period. One would perhaps assume on logical grounds that the authorities of racially constituted states where the politically dominant group was a minority, would have wanted to boost their numbers. Yet for much of the period, elites held back because they saw incomers as potentially disruptive elements, political radicals, or as disturbers of racial boundaries. The view was put in extreme form in the early 1930s by Belgian Congo Governor Pierre Ryckmans, who opined that "the "poor whites", blancs pauvres, are pariahs. ... Sending emigrants to the Congo in order for them to reconstruct their lives equals condemning them to the destiny of natives' ${ }^{40}$ In Southern Rhodesia, the new state authorities took an extremely sceptical view of immigrants, driven by fears of the "poor white" problem. This was underpinned by concerns about the perennially depressed condition of the economy and thus the need to protect white Rhodesian unemployed. In the 1930s Rhodesian Prime Minister Huggins quite explicitly articulated the view that Rhodesia could not absorb large numbers of white immigrants; settler society was not under immediate political threat and Huggins's view was that that a large white working class would, dangerously push for high wages and seek to exercise political power. ${ }^{41}$ Portuguese policy towards immigration to the colonies in the 1930s was focused on sending technical cadres, engineers, specialists and managers. Those wanting to emigrate to the colonies on a private basis had to show a high income or an invitation guaranteeing employment. This approach was driven by the fear of creating a stratum of unemployed and poor whites. ${ }^{42}$

Even when such policy was reversed, as it was in the Portuguese colonies from the late 1940s to the end of the colonial period, there was often dismay at the actual settlers who materialised. A Portuguese official report in 1970 concluded that

The settler who comes to [Mozambique] ... is of such a modest social and economic standing that he is frequently more of a disruptive element than a useful one. With a happy few exceptions [these settlers] show themselves completely lacking in any skills, and are largely difficult, if not impossible, to keep on the virtuous path (particularly those that arrive clandestinely). The majority lacks the mentality to secure their livelihood, much less to be attentive to their civilizing function with respect to the native population. ${ }^{43}$

It was only after the Second World War that Portuguese and Rhodesian leaders warmed towards immigration. Under new pressure in a decolonising world, and with more money to spend as a result of the post-war boom, they were 
now ready to put racial demographics ahead of considerations of how to manage the white lower orders. There was a temporary explosion of the size of the white population in the region outside South Africa, from about 200,000 at the end of the Second World War, to approaching a million at the start of the 1970s. Southern Rhodesia moved from only 69,000 whites in 1940 to 27,100 in 1970 , and Northern Rhodesia from a paltry 13,000 in 1940 to 75,000 in 1960. Most proportionately spectacular though was the growth of the white population of the Portuguese colonies. In 1940 there were under 100,000 whites in Mozambique and Angola combined. By 1970, there were at about half a million and possibly more, roughly 60 per cent in Angola and 40 per cent in Mozambique. ${ }^{44}$ In addition, by the early 1970s there well over 100,000 Portuguese troops in Angola and Mozambique.

In the future South Africa, the great inflow of British settler population occurred under the impetus of the gold mining expansion of 1890 to 1906. After the formation of the Union in 1910, state immigration policy was largely hostile to immigration. Afrikaner nationalists feared that British immigrants would oppose them at the ballot box, and elites in general feared the import of working-class radicalism. There were only two moments of large scale United Kingdom immigration. In the immediate aftermath of the Second World War, the Smuts government turned towards immigration from Britain and elsewhere in Europe, but the Nationalists quickly shut down this policy after coming to power in 1948. In the early 1960s, a shortage of white artisans led to a modest opening to British immigrants. A large proportion of these were artisans. Stone's study of this cohort suggested that contrary to stereotype, they were by and large not reactionaries attracted by apartheid, but rather were pursuing economic opportunities. He showed they tended to absorb South African racial attitudes fairly quickly, but that they were notably sympathetic to trade unionism, including for black workers. ${ }^{45}$

Intra-regional white migration is a phenomenon that needs to be better understood. As Robert Bickers usefully suggests, this "unsettled" dimension of supposed "settler" life is worth investigating. ${ }^{46}$ The world of the British Empire was often one of searches for short-term opportunity rather than long-term settlement. "Settler" is a misnomer for such a strikingly unstable social category of trans-imperial sojourners. Two instances of this are worth particular comment. One is the peculiar turbulence of Rhodesian migration. Rhodesia always had a huge immigration turnover. South Africans and Britons especially, flowed in and out with remarkable velocity, throughout the life of the Rhodesian state. ${ }^{47}$ They appeared remarkably sensitive to the pushes and pulls of Rhodesia's highly changeable economic and political prospects. Another is the history of Portuguese migration to South Africa, mainly via Mozambique. ${ }^{48}$ Starting with the flow of mainly very poor Madeirian workers, often working under conditions of mutual exploitation in fellow-islanders' market gardens that fed South African cities, it developed through a more gradual and socially differentiated migration of mainlanders through the post-Second World War period. It culminated in the mass migration following the collapse of the empire which made 
a significant impact on South African cities. Portuguese immigrants formed a number of communities in South African cities, most notably in Johannesburg southern suburbs areas like Turffontein, La Rochelle and Rosettenville. Though many had lost everything in the collapse, over time they were able to get upwards social mobility through success as artisan skills and small business. Across the whole period, South African resistance to Portuguese migration was considerable, and certainly informed by anti-Catholic religious ideologies.

\section{Struggles for cultural dominance}

The white working classes of Southern Africa were a field of struggles for cultural dominance. In the British Empire countries there can be little doubt that, early in the twentieth century, imperial elites were determined to impose their cultural hegemony on whites and indeed to a considerable extent on blacks. However, British working-class immigrants also brought their subaltern cultural institutions, organisations and practices, from dog racing to fraternal organisations. And even by the 1920s, with the arrival of the silent movies and the spread of the gramophone, the challenge of American influence on white workers was bothering both Afrikaner and Anglophone elites.

In South Africa, Southern Rhodesia, and the emerging enclave of white labour on the Northern Rhodesia Copperbelt, there was a stabilisation and quasi-indigenisation of the British models of working-class life that had been brought to the region by the mass migration of the 1890 to 1906 . The apprenticeship system and the pivotal position of artisans in industry and services had become very firmly established. The artisan world was initially British dominated to a massive extent, with a large majority of "skilled men" being immigrants as late as the 1920s. This created a tension between artisan unions and the new Afrikaner workforce. There were also quite a number of "Coloured" qualified artisans, trained in the Cape. Over time however the system became both more racialised and more Afrikanerised. A specifically artisan culture stamped a number of the industrial towns of the area. Bulawayo, as the Rhodesian rail and industrial centre, was perhaps the classic example, with its white skilled workers clubs, communal activities and even a labour movement store, and the Rhodesian Labour Party dominating electoral politics in working-class areas. ${ }^{49}$ The British artisan tradition had a last wave of reinforcement with the $1960 \mathrm{~s}$ emigration to Southern Africa. In 1960s Johannesburg, British artisans were a visible presence; soccer and dirt track motorbike racing flourished, popular British television personalities made tours, and the Daily Mirror was the standard reading in Johannesburg barber shops.

The region saw two spectacular attempts to impose cultural autarky on the working class. These were the projects of the Portuguese Estado Novo and of Afrikaner nationalism. Both were anti-modernist at a cultural level, while at the same time being invested in the idea of technological modernity. And both had a particular emphasis on shielding subaltern whites from the supposedly disintegrating effects of cosmopolitan culture. Both offered workers a nostalgic 
vision of an idealised rural world. In the long run the subaltern whites who they were intending to protect succumbed to external forces, in particular, the power of Americanised global consumer culture.

An extraordinary example of this cultural anti-modernism was the attempt by the Portuguese to establish model agricultural colonies in Angola. Based on a fantasy of the idealised virtues of the Portuguese peasantry, it aimed to set up villages which would not only embody Catholic and authoritarian political ideals, but also provide African peasants with a model of how farming should be carried out. In the areas of Cela and Cunene peasant families and extremely poor rural workers from the metropolis were settled. But they faced harsh conditions and the planning of the projects left much to be desired. Many of the farmers gave up, drifting into the towns, where they worked in low level civil service posts, office jobs or as petty traders ${ }^{50}$ But the vast majority of settlers came at their own initiative, albeit with state encouragement, and chose to settle in the cities, where the hegemony of Salazarism gradually weakened. In Angola, by 1970, 77 per cent were urban. In Mozambique, the influence of consumer culture on Lourenco Marques became very strong via the South African tourist presence and commercial connections to Johannesburg. And also cutting against cultural conservatism, the vast scale of Portuguese migration to France during the 1950s and 1960s diffused dissident ideas into the home country and thence into the colonial world.

During the 1950s and 1960s, amongst Afrikaners a high level of social discipline and cohesion was ensured through the incorporation of working-class and lower-middle-class Afrikaners into a network of organisations designed to regulate every sector of life, from women (Vrouefederasie) to youth (Voortrekkers). But these attempts to round up whites into a volk culture were constantly threatened. Already in the 1950s, the state was worried though about white working-class youth groups like the "Ducktails", whose blend of British and American rocker youth styles, drug taking, blurring of racial boundaries in clubs and casual violence made them a prime example of what officials feared about cultural globalisation..$^{51}$ While the degree of upwards class mobility in this period has probably been overstated, the size of the improvement in white working-class living standards had been underestimated. White real wages in manufacturing and construction doubled between 1948 and 1972, and in mining by only a little less. ${ }^{52}$ The new consumption patterns this enabled changed white working-class life. Near-universal car ownership enabled families to enjoy new leisure activities like the drive-in cinema, roadhouse meals and seaside holidays. ${ }^{53}$ “Ag Pleez Daddy," Jeremy Taylor's famous song of the early 1960s, reflected the contempt of Johannesburg's Anglophone bourgeoisie for the new affluence of the white workers, sending up their outings to the "bioscope" (cinema), funfair, the wrestling and trips to Durban ('only eight hours in the Chevrolet'). But such snobbish resentment was surely scarcely noticed by its targets. The Afrikaner cultural organisations and reformed churches, with their strong association with the political establishment, over time lost their appeal to the working class. By the 1980s the growing preferences of Afrikaner workers 
for Country and Western over Boeremusiek and Pentecostalism over the Dutch Reformed Church were apparent. These were important and serious issues, because the viability of the political projects of state leaders and of activists to an important extent stood or fell by the ability to marshal political identities. And while in theory extreme white right wingers looked back to a golden age of ethnic identity, social unity and conservative discipline, in practice they were susceptible to the cosmopolitan attractions of casino gambling, American television sitcoms and videotape pornography.

\section{Endings: workers between Racial Keynesianism and free marketism}

In our contemporary global perspective, free market ideology is the favoured viewpoint of those who are indifferent or hostile to issues of racial and class equality, whereas more racially and economically egalitarian political actors tend to support interventionist policies. By contrast, in twentieth-century white-ruled Southern Africa, both free market and statist economic policy was harnessed in various ways to racial domination, with economic interventionism being particularly favoured by white populists. One might characterise this phenomenon as Racial Keynesianism.

The Botha-Smuts governments of 1910 to 1924, the Estado Novo before 1945, and the political regime of pre-Second World War Southern Rhodesia, did relatively little for the white working class. In contrast, as we have seen, South African governments from 1924 took an interventionist course, with favourable, racially discriminatory outcomes for the white workers. This lead was followed by settler governments in the Rhodesias and the Portuguese colonies after the Second World War. These regimes moved in an increasingly white-welfarist direction and poured money into employment-generating prestige projects, whether dam building, the development of airlines, road construction or the establishment of new schools and universities.

However, in the end, the elites abandoned the white working class. In Portugal, during 1974-5 the new, democratised state moved quickly to depart from Africa, leaving the colonial white workers to their own devices. From 1974 to 1975 , when Ian Smith began negotiating seriously with African nationalist leaders, Rhodesia rapidly moved away from white worker protectionism. The protests of extremist groups like the Rhodesia Action Party failed to prevent the ultimate transition of power. ${ }^{54}$ In South Africa, the growing Afrikaner middle class were increasingly uncomfortable in the embrace of the populism. They aspired to globalised patterns of consumption and acceptance by their metropolitan peers. They gradually lost their social connections to the white working class. Moreover, white business was aware that the low black consumption levels and labour shortages which apartheid had produced were strangling the economy. The leaders of the National Party found the sacrifice of the special privileges of the white working class increasingly easy to contemplate as part of their search for solutions. One after another, regulations and laws protecting 
white workers began to be reversed. The rapid increases in white working-class standards of living of the previous period were not sustained: white real wages fell substantially from the second half of the seventies. ${ }^{55}$ As black trade union movements became powerful, white workers faced challenges to their racial authority from their black counterparts. A palpable sense of dislocation existed amongst white workers, finding expression in support for the parties of the extreme right: but ultimately their resistance to the move away from apartheid was to be of no avail.

\section{Conclusion}

In Southern Africa, "the white working class" and the "poor whites" were neither simple sociological categories, nor ones that can adequately be thought through within the boundaries of individual states. Who white workers and poor whites were, and what their significance was, was an endlessly refought political battle. They did not live in single national space but moved across the region. Their concerns were not purely parochial but related to transnational politics. They should perhaps be thought of not so much as "white people", as but members of particular classes who were called "white", by others, or by themselves, for particular ends, in distinct moments of global, regional and local historical time.

\section{Notes}

1 Fetter, Creation of Elisabethville, 66-68; Perrings, Black Mineworkers in Central Africa, 50-53; Report by D.I. Jones to Comintern, 13 August 1921, Davidson, Filatova, Gorodnov and Johns, South Africa and the Communist International, 87; Sidney Ball, 'Belgian Congo', Engineering and Mining Journal, 22 January 1921, 191.

2 Russell and Russell, Afrikaners of the Kalahari, 24-26.

3 Brás, 'The Twists and Turns of Life', 148-160.

4 Katz, Trade Union Aristocracy; Krikler, White Rising.

5 O'Meara, Volkskapitalisme, 78-95.

6 Morrell, White but Poor is a key text.

7 Boonen and Lagae, 'A City Constructed', 59.

8 See Stoler, 'Rethinking Colonial Categories'.

9 Notably in Bender, Angola Under the Portuguese.

10 Pimenta, 'Angola's Whites'.

11 Errante, 'White Skins, Many Masks', 21-22.

12 According to Lubkemann, 'Unsettling the Metropole', 265-266, Portuguese citizens returning from the colonies in 1974-1975 has a significantly higher level of education and employment skills than their metropolitan counterparts.

13 Crankshaw, Changing Division of Labour, 141-171.

14 Pimenta, 'Angola's Whites', especially 178.

15 Errante, 'White Skins, Many Masks'.

16 Crankshaw, Changing Division of Labour, 141-177.

17 Penvenne, 'Labor Struggles at the Port of Lourenco Marques'.

18 Clarence-Smith, Third Portuguese Empire, 1825-1975, 178.

19 Ribeiro de Menzes, Salazar:A Political Biography.

20 Harvey, 'Counter-Coup in Lourenco Marques'. 
21 Fetter, Creation of Elisabethville, 68-71, 97, 101, 173.

22 Giliomee, The Afrikaners, 336-345.

23 Leys, European Politics in Southern Rhodesia, 180-185; Lowry, 'Rhodesia 1890-1980', 113-149.

24 On Anderson, and poor whites more generally, see Cairnie, Imperialists in Broken Boots.

25 Schwarz, Memoirs of Empire, 361-363.

26 Welensky, 4000 Days, 21.

27 Hyam and Henshaw, Lion and the Springbok, 208-227. Also interesting on the politics of the Afrikaner presence in the Rhodesias in this period is Winch, 'Rhodesia, Rugby and the Afrikaner'.

28 My original statement of this position can be found in Hyslop, 'The Imperial Working Class', 398-421.

29 Lunn, Capital and Labour, 90-96; Phimister, 'White Miners in Historical Perspective'; Henderson, 'White Populism in Southern Rhodesia'.

30 Money, 'The World of European Labour'.

31 Lunn, Capital and Labour, 93.

32 Van der Walt, 'Transnational Labour Activism in Southern Africa, 235.

33 For McPherson see Walker and Weinbren, 2000 Casualties, 204, 300, 324-326, 335; for Maasdorp see Steele, 'White Working-Class Disunity'.

34 Roos, Ordinary Springboks.

35 Money, 'The World of European Labour', 235-239, 248-251.

36 Clarence-Smith, Third Portuguese Empire, 178.

37 Hepple, Verwoerd, 66.

38 Schwarz, Memories of Empire, 367-377.

39 Lowry, 'The Impact of Anti-Communism'.

40 Boonen and Lagae, 'A City Constructed', 55.

41 Mlambo, White Immigration into Rhodesia, 44-45.

42 Castelo, 'Reproducing Portuguese Villages', 272.

43 Errante, 'White Skins, Many Masks', 20.

44 The statistics for the region are usefully brought together in Pimenta, 'Angola's Whites', 171.

45 Stone, Colonist or Uitlander; see 197 for views on trade unionism.

46 Bickers, Empire Made Me, 242.

47 Mlambo, White Immigration into Rhodesia, 5.

48 Glaser, 'Portuguese Community in South Africa'.

49 Ranger, Bulawayo Burning, 31-38.

50 Castelo, 'Reproducing Portuguese Villages', 267-281.

51 Mooney, 'Ducktails, Flick-knives and Pugnacity'.

52 Lipton, Capitalism and Apartheid, 409-410.

53 Beinart, Twentieth Century South Africa, 179-190.

54 Godwin and Hancock, Rhodesians Never Die.

55 Lipton, Capitalism and Apartheid, 409. 